\title{
BIOINDICATION OF WATER QUALITY \\ OF THE XINLICHENG RESERVOIR BY ALGAL COMMUNITIES
}

\author{
Sophia BARINOVA *, Na LIU **, Jiyang DING **, \\ Yonglei $A N^{* *}$, Xueming QIN ** and Chenxin WU ** \\ * Institute of Evolution, University of Haifa, Mount Carmel, Abba Khoushi Avenue, 199, Haifa, Israel, \\ IL-3498838, sophia@evo.haifa.ac.il \\ ** Jilin University, Key Laboratory of Groundwater Resources and Environment, Changchun \\ CN-130021, China, liuna@jlu.edu.cn, dingjiyang321@163.com, anyonglei85@jlu.edu.cn, \\ 709455130@qq.com, 1172227543@qq.com
}

DOI: 10.2478/trser-2020-0014

KEYWORDS: phytoplankton, periphyton, water quality, self-purification, China.

\section{ABSTRACT}

The ecological analysis of 31 algae and cyanobacteria indicators assessed the water quality of the Changchun drinking water Xinlicheng Reservoir by using bio-indication methods. The water was fresh, low alkaline, low-saline, middle oxygenated, with reached nutrients and organic pollution and mesotrophic to eutrophic. Statistics reveal significant variables that impacted algal diversity were nutrients, water quality was low to the middle polluted Class II-III. The indices of saprobity and WESI show the high self-purification capacity and low-toxicity impact. We revealed potential threatening species of cyanobacteria. The improving water quality from 2007 up to now has been revealed.

ZUSAMMENFASSUNG: Bioindikation der Wasserqualitat des XinlichengReservoirs durch Algengemeinschaften.

Mit Hilfe einer ökologischen Analyse von 31 Algen- und Cyanobakterienindikatoren wurde die Wasserqualität des Changchun-Trinkwasser-Xinlicheng-Reservoirs unter Anwendung von Bioindikationsmethoden bewertet. Dabei ging es um Süßwasser, das niedrig alkalisch, salzarm, und mittel sauerstoffhaltig war, angerreichert an Nährstoffen sowie organischer Verschmutzung und meso- bis eutroph. Statistiken zeigen, dass signifikante Variablen, die Algenvielfalt beeinflussten, Nährstoffe waren und die Wasserqualität bis zur mittleren verschmutzten Klasse II-III niedrig war. Die Indizes für Saprobität und WESI zeigen die hohe Selbstreinigungskapazität und die geringe Toxizität an. Es wurden potenziell bedrohliche Arten von Cyanobakterien entdeckt. Von 2007 bis heute wurde eine Verbesserung der Wasserqualität festgestellt.

REZUMAT: Bioindicaţia calităţii apei a rezervorului Xinlicheng prin comunităţi algale.

Analiza ecologică a 31 de indicatori de alge și cianobacterii indicatoare a evaluat calitatea apei din rezervorul Xinlicheng a apei potabile Changchun utilizând metode de bio-indicație. Apa era dulce, slab alcalină, cu salinitate redusă, cu conținut mediu de oxigen, cu substanțe nutritive corespunzătoare, poluare organică și mezotrofă până la eutrofă. Statisticile relevă variabile semnificative care au influențat diversitatea algelor în nutrienți, calitatea apei a fost scăzută până la clasa II-III poluată mijlociu. Indicii de saprobitate și WESI arată capacitatea ridicată de auto-purificare și impactul toxic redus. Au fost identificate specii de cianobacterii potențial amenințătoare. S-a constatat îmbunătățirea calității apei din 2007 până în prezent. 


\section{INTRODUCTION}

The maintenance of water quality at a high level is of considerable importance. For the most part, the water comes from natural sources, including rivers, lakes, and reservoirs. The quality of their water should be not only assessed but also predicted. Under natural conditions, water quality depends on the river watershed and the ecosystem of the water body. Considering that water quality assessment is rather expensive, elaboration of express-methods of its assessment is an urgent problem. Special attention is given to the water quality of natural water bodies used as drinking water sources. Because these types of body of water are an open natural system, many influences can affect its water quality. Usually, reservoirs are protected when it is possible, but in some circumstances, pollutants can inflow into its water.

Pollution in freshwater is represented as a complicated system of problems. Therefore, the methods for diminishing the impact of pollution requires more understanding of the ecosystem structure as well as in assessing the relevancy of methods for its state assessment. The methods and indices that can be used to evaluate the pollution impact on natural water bodies are based on the ecological point of view to the water and biota relationships. Protein production is provided by primary producers at the first level of the trophic pyramid; therefore, it can be assumed that algae can be used as bioindicators of the impact of pollution. Our Data Base of species-specific ecological preferences (Barinova et al., 2006, 2009) includes the freshwater algae grouping concerning the significant variables: $\mathrm{pH}$, salinity, temperature, streaming and oxygenation, saprobity, nutrition type, and trophic level. This helps us to assess the water quality and ecosystem state with a systemic approach.

One of the parts of the aquatic ecosystem that is most suitable for the ecological evaluation of water quality is freshwater algae (Bellinger and Sigee, 2010). Therefore, many algal species are used as environmental indicators for the assessment of water quality. A bioindication approach has been implemented previously for the assessment of the water quality in the upper reaches of the Songhua River (Barinova et al., 2016) in China. This method yields productive results in the ecological assessment of water quality of other bodies of water close to this region like in India (Barinova et al., 2012) and the Russian Far East (Barinova et al., 2008, 2015).

Water supply and sanitation in China is undergoing a massive transition while facing numerous challenges such as rapid urbanization and a widening economic gap between urban and rural areas (BBC News, 2007).

The quality of groundwater or surface water is a significant problem in China because of man-made water pollution (Sun, 2011) or natural contamination (Browder et al., 2007; Ma, 2007). For this purpose, we implemented a new bio-indication methods for China (Barinova et al., 2016) for the water quality assessment that is important for large rivers, lakes, and reservoirs (Zalewski, 2000) like the Xinlicheng Reservoir (Berdnikov et al., 2006; Sun, 2011; Barinova et al., 2015) placed in the upper reaches of the Songhua River watershed. This reservoir takes our attention because a few years ago, there was an ecological incident that influenced the water quality (Sun, 2011). Some researchers have assessed water quality by chemical methods and by phytoplankton production, but bioindicational assessment of the reservoir was done for the first time on the frame of Sino-Israeli International Scientific Expedition in July 2015.

The aim of the present study is to assess the Xinlicheng Reservoir water quality by using bio-indication methods based on ecological preferences of phytoplankton and periphytonic algae statistical approach. 


\section{MATERIAL AND METHODS}

\section{Study area and its major problems}

The Xinlicheng Reservoir is located southeast of Changchun City (Fig. 1), the capital

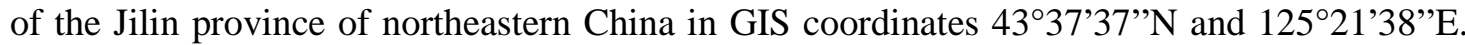
Water from the reservoir is used as the drinking source for Changchun.

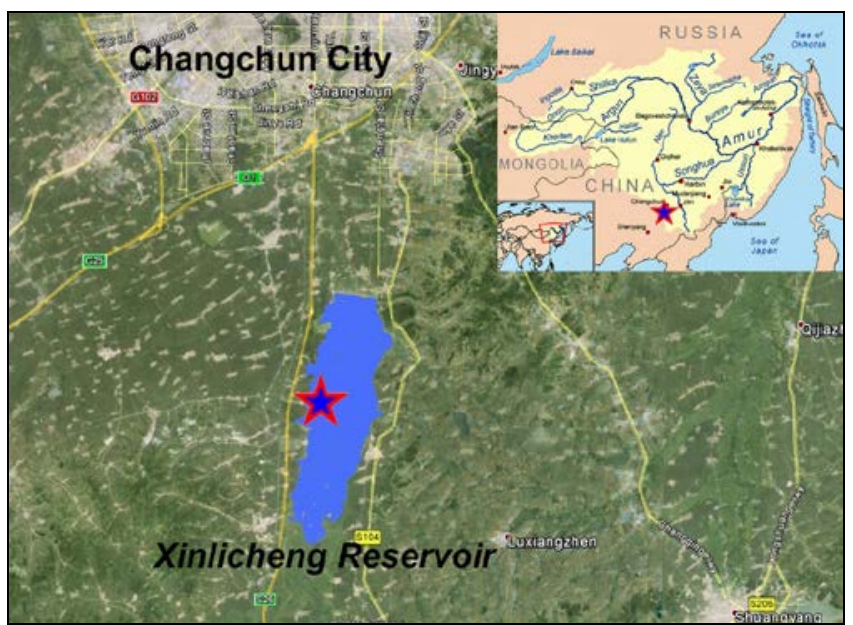

Figure 1: Sampling site ( $\star$ ) in the Xinlicheng Reservoir in July 2015.

The reservoir is placed between the hills, filled by rainwater, and its water surface is about $70 \mathrm{~km}^{2}$. Its function includes aquaculture, flood-control, and anti-drought (Kao et al., 2013). Its volume is about $5.9210^{9} \mathrm{~m}^{3}$ and carrying capacity is up to $2.52910^{9} \mathrm{~m}^{3}$ of water. In the hot climatic summer season of 2007, the cyanobacteria erupted, and algal bloom occurred in Xinlichen Reservoir. Although the Changchun administration has adopted some techniques to reduce bloom, this problem recurs from time to time in this important drinking resource in the province ( $\mathrm{Li}$ and Han, 2007). In the following years, attempts were made to find tools for assessing water quality, managing and predicting bloom, and assessing the trophic status of the reservoir. However, only monitoring data were used for chemical indicators and, sometimes, the number of plankton algae or the amount of chlorophyll (Xian et al., 2014). As a result, not only blue-green algae, but also diatoms and green algae (Kao et al., 2013) were identified as common species. The trophic status of the reservoir was initially assessed as eutrophic, and then, by 2011, as weakly eutrophic. Moreover, it was found as a result of studying the seasonality of phytoplankton development that the water body is most susceptible to eutrophication during the rainy winter season, while in the dry summer period, its trophicity decreased (Xian et al., 2013) on the base of Chlorophyll-a analysis. Thus, the role of nutrients stimulating the development of algae was revealed, as well as the catchment area, pollution from which is introduced into the water of the reservoir during the rainy season. This was indicated even during the study of the first catastrophic bloom in 2007 when the reservoir was cut off from the water supply system, and 24,000 people were left without drinking water (BBC News, 2007). The ingress of nitrogen and phosphorus compounds into the reservoir were leaked from economic and industrial enterprises located near the coast of the reservoir. However, in subsequent years, studies did not address the relationship between pollution of the catchment area with water quality and cyanobacterial blooms. The Sino-Israeli International Expedition carried out research on the water quality in the reservoir using modern methods of bioindication and statistics. 


\section{Sampling and identification}

Material for work comes from 10 phytoplankton and 10 periphyton samples collected in July 2015 from four sampling sites of the Xinlicheng Reservoir (Figs. 2 and 3) (Tab. 1). Phytoplankton was collected along the reservoir shore with the Apstein phytoplankton net, gas 20 mesh. Periphyton was scrape (epilithic) and squeezed (epiphytic), placed in 10-ml plastic tubes, and fixed with 3\% neutral formaldehyde solution. Samples of phytoplankton were placed in sampling tubes of $50 \mathrm{ml}$, partly fixed in the $3 \%$ neutral formaldehyde solution, and partly left as living for the study in the laboratory. In parallel with the phytoplankton samples in each site were taken samples of water about one liter for total analysis and $0.5 \mathrm{l}$ for the BOD analysis with fixation. All samples were transported to the laboratory in an icebox.
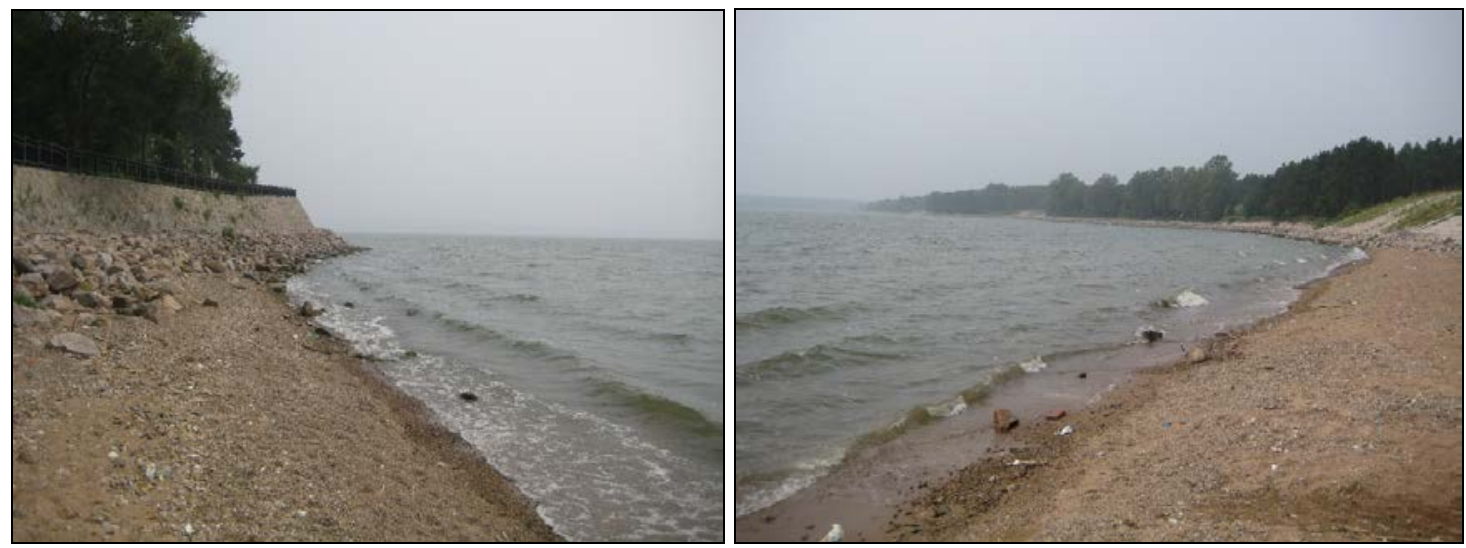

Figure 2: The reservoir shore in sampling site of the Xinlicheng Reservoir in July 2015.
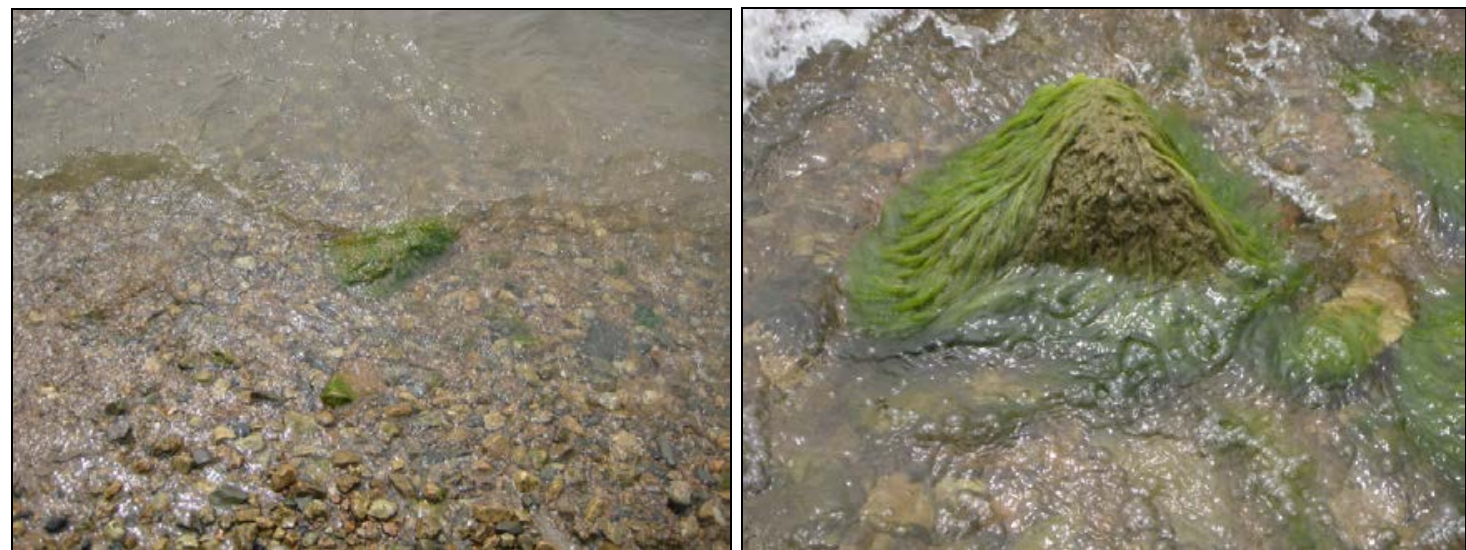

Figure 3: Algal communities on the sampling sites in the Xinlicheng Reservoir in July 2015.

Temperature was measured in the site with a thermometer and water transparency by the white Secchi disk. Acidity (pH), conductivity (EC), and TDS were measured with HANNA HI 9813-0. Measurements were made by adding the probe into the water until the reading was stabilized. Chemical variables were analysed in the Key Laboratory of Groundwater Resources and Environment, Ministry of Education, Jilin University according to EPA standard methods. The concentrations of some parameters were detected with the Chinese National Standard, as follows: biochemical oxygen demand $\left(\mathrm{BOD}_{5}\right)$, GB/T11901-1989, chemical oxygen demand $\left(\mathrm{COD}_{\mathrm{Cr}}\right)$, GB/T11914-1989, total nitrogen (TN), GB/T11894-1989, ammonia nitrogen, GB/T7479-1987, GB/T11893-1989. The concentrations of nitrite, nitrate, chloride, phosphate, and sulfate were measured by Ion chromatography (DIONEX ICS-2100). 
Algae were studied in the live and fixed state using SWIFT-M4000-D and OLYMPUS BX-40 dissecting microscope under magnifications 740x-1850x from three repetitions of each sample and were photographed with a DC (OMAX A35100U). For the study of diatoms were made permanent slides (Swift, 1967) modified for glass slides (Barinova, 1997) and were fixed in Naphrax ${ }^{\circledR}$ resin from two repetitions of each sample. Identification of the algae species was made using the relevant handbooks (Krammer and Lange-Bertalot, 1986, 1988, 1991a, 1991b; John et al., 2011), and their current scientific names were updated according to algaebase.org (Guiry and Guiry, 2018).

The frequency of the species was evaluated according to the six-score scale (Barinova et al., 2006; Barinova, 2017a). Water Ecosystem State Index (WESI) of aquatic ecosystem sustainability was calculated according to Barinova et al. (2006, 2009; 2017b) as (1): WESI = Rank S/Rank N-NO ${ }^{3}$ (1), where: Rank S - rank of water quality on the Sladeček's indices of saprobity; Rank N-NO $\mathrm{NO}_{3}$ - rank of water quality on the nitric-nitrogen concentration (Tab. 1).

If WESI is equal to or larger than one, the photosynthetic level is positively correlated with the level of nitrate concentration, if is less than one, the photosynthesis is suppressed, presumably according to toxic disturbance (Barinova et al., 2006; Barinova, 2017b).

The autecological data of the species were taken from our database (Barinova et al., 2019) according to substrate preference, temperature, oxygenation, $\mathrm{pH}$, salinity, organic enrichments, N-uptake metabolism, and trophic states. The ecological groups were separately assessed according to their significance for bio-indications. Species that respond predictably to environmental conditions were used as bio-indicators for particular variables of aquatic ecosystems, the dynamics of which are related to environmental changes. The statistical methods are those recommended by Heywood (2004) for the development of floristic and taxonomic studies in Eastern Asia. The JASP program (Love et al., 2019) was used in comparative data approaches for calculating the similarity of algal communities in the studied sites. CANOCO program was used for the calculation of biological and environmental variables relationships (Ter Braak and Šmilauer, 2002). The water quality class is defined according to the EU 5-Classes system based on the species indicators content (Barinova et al., 2006, 2019; Barinova, 2017b).

The list of the algae species was combined with an ecological database in Office Access (Microsoft). The BiodiversityPro program was used for the Shannon indices calculation. Statistica 12.0 program was used to construct the plots of the relationships between biological and environmental variables.

\section{RESULTS AND DISCUSSION \\ Environmental variables}

Environmental properties of water in the studied reservoir are given in table 1, where it can be seen that all variables values are varied in a narrow range because the sites are close to each other. All measurements were done on one date as screening. Nevertheless, water $\mathrm{pH}$ was circumneutral; transparency was low at about $0.3 \mathrm{~m}$, and water conductivity and total dissolved solids (TDS), turbidity (TSS) fluctuate synchronously. Studied reservoir water was sufficiently oxygenated, and the value of COD, chlorides, and sulfates was low and typical for freshwater lakes and reservoirs (Barinova 2017b). On the contrary, BOD, the forms of nitrogen and phosphorus, which normally should be in the same range, were in the middle range, which showed some periodic excessive enrichment of water with nutrients, which indicated their allochthonous, but not the autochthonous origin, as it was concluded for the Xinlicheng Reservoir earlier (Xian, 2013). 
Table 1: Major averaged chemical and biological variables in the Xinlicheng Reservoir, July 2015.

\begin{tabular}{|c|c|c|c|}
\hline Variable & $\min$ & $\max$ & STDEV \\
\hline Secchi visible depth, cm & 25 & 30 & 3.536 \\
\hline $\mathrm{pH}$ & 8.7 & 8.9 & 0.141 \\
\hline $\mathrm{DO}, \mathrm{mg} \mathrm{L}^{-1}$ & 8.85 & 8.95 & 0.071 \\
\hline $\mathrm{T},{ }^{\circ} \mathrm{C}$ & 29.0 & 29.1 & 0.071 \\
\hline Conductivity, $\mathrm{mSm} \mathrm{cm}^{-1}$ & 0.33 & 0.33 & 0.0 \\
\hline TDS, $\mathrm{mg} \mathrm{L}^{-1}$ & 240 & 243 & 2.121 \\
\hline TSS, $\mathrm{mg} \mathrm{L}^{-1}$ & 13 & 14 & 0.707 \\
\hline COD, $\mathrm{mg} \mathrm{L}^{-1}$ & 28 & 30 & 1.414 \\
\hline $\mathrm{BOD}, \mathrm{mg} \mathrm{L}^{-1}$ & 5.75 & 5.81 & 0.042 \\
\hline $\mathrm{TN}, \mathrm{mg} \mathrm{L}^{-1}$ & 6.20 & 6.31 & 0.078 \\
\hline $\mathrm{N}-\mathrm{NH}_{4}{ }^{+}, \mathrm{mg} \mathrm{L}^{-1}$ & 0.08 & 0.1 & 0.014 \\
\hline $\mathrm{N}-\mathrm{NO}_{2}^{-}, \mathrm{mg} \mathrm{L}^{-1}$ & 1.20 & 1.47 & 0.191 \\
\hline $\mathrm{N}^{-\mathrm{NO}_{3}}{ }^{-}, \mathrm{mg} \mathrm{L}^{-1}$ & 1.12 & 1.20 & 0.057 \\
\hline $\mathrm{P}_{-} \mathrm{PO}_{4}{ }^{3-}, \mathrm{mg} \mathrm{L}^{-1}$ & 3.45 & 3.54 & 0.064 \\
\hline $\mathrm{Cl}^{-}, \mathrm{mg} \mathrm{L}^{-1}$ & 24.55 & 24.61 & 0.042 \\
\hline $\mathrm{SO}_{4}{ }^{2-}, \mathrm{mg} \mathrm{L}^{-1}$ & 40.1 & 40.42 & 0.226 \\
\hline $\mathrm{Cl}^{-}, \mathrm{mg} \mathrm{L}^{-1}$ & 24.55 & 24.61 & 0.042 \\
\hline $\mathrm{SO}_{4}{ }^{2-}, \mathrm{mg} \mathrm{L}^{-1}$ & 40.1 & 40.42 & 0.226 \\
\hline \multicolumn{4}{|c|}{ Species in Division } \\
\hline Cyanobacteria & 6 & 7 & 0.707 \\
\hline Bacillariophyta & 6 & 6 & 0.000 \\
\hline Chlorophyta & 12 & 14 & 1.414 \\
\hline Charophyta & 2 & 2 & 0.0 \\
\hline Total Species number & 26 & 31 & 2.121 \\
\hline \multicolumn{4}{|c|}{ Species in Division } \\
\hline Cyanobacteria & 23 & 25 & 1.414 \\
\hline Bacillariophyta & 9 & 9 & 0.000 \\
\hline Chlorophyta & 31 & 40 & 1.414 \\
\hline Charophyta & 3 & 3 & 0.000 \\
\hline Total frequency scores & 66 & 77 & 2.828 \\
\hline Index Saprobity S & 1.85 & 1.97 & 0.085 \\
\hline Index WESI & 0.8 & 0.8 & 0.0 \\
\hline Shannon Index & 3.259 & 3.312 & 0.037 \\
\hline
\end{tabular}

\section{Algal diversity and abundance}

A total of 31 species of algae and cyanobacteria has been identified from 20 algal samples collected from four sites the richest but also abundant in the summer communities of the Xinlicheng Reservoir. We revealed differences in the distribution of species richness and abundance (as frequency scores) in four taxonomic Divisions (Fig. 4). Whereas species richness increased in line Charophyta - Cyanobacteria - Bacillariophyta - Chlorophyta, the cells abundance in Division have another order: Charophyta - Bacillariophyta - Cyanobacteria - Chlorophyta. This difference can reflect the species preferences in the biomass production for Chlorophyta and Cyanobacteria in contrary to diatom and charophyte algae. It is remarkable that the same distribution has been found in the summer communities of the 
Songhua River in the catchment basin of which the studied reservoir is located (Barinova et al., 2016). Therefore, we can define that prevalence of green algae with followed cyanobacteria can be the face profile of aquatic communities of this region.

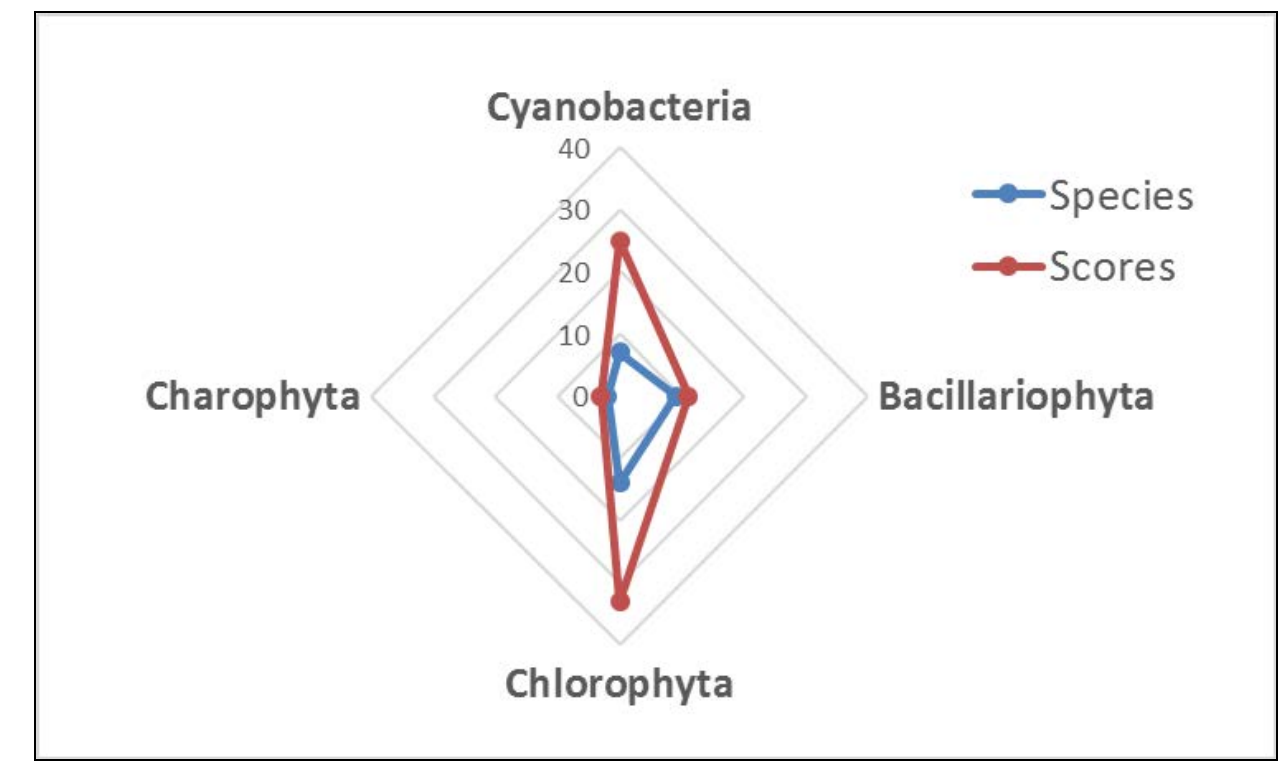

Figure 4: Distribution of species number and frequency scores in taxonomic Division in the Xinlicheng Reservoir, July 2015.

\section{Bio-indication properties}

Bioindication properties of all revealed species can be seen in table 2. We summarized revealed indicators over groups of indicated variables (Fig. 5). Moreover, in order to identify the most favorable indicator groups in the communities of the Xinlicheng Reservoir, we compared the distributions of the number of indicator species with the sum of the scores of each group. Table 2 and figure 5 show that planktonic-benthic species prevail in number, but the true planktonic organisms were also abundant. In species number and abundance, the group of preferred middle oxygenated waters species prevail, but interestingly, there were also abundant species that preferred standing water and those that preferred the tide zone. It means that oxygenation indicator abundance can be a character of a large water reservoir in which the surf zone is essential for the formation of algal communities. Among indicators of salinity, species with freshwater ecology prevailed, both in number and in abundance. Indicators of the Water Quality Class 3 were sufficient prevail in species number and in abundance with followed Class 2 species. Distribution of the nitrogen-uptake metabolism indicators demonstrated the prevalence of autotrophic species number (ats) but at the same time dominance of facultatively heterotrophic species (hce) in total abundance. Here we can mention Nitzschia acicularis not only as an organism with heterotrophic possibilities, but also as an indicator of organic pollution with a species-specific index of Saprobity 2.7. Most important in bioindication of water quality is the assessment of the reservoir trophic state, especially if this water body is used as a drinking water resource. Figure 5 shows only three groups of trophic state indicators placed on the plot in respect of increasing the group trophicity. It can be seen that both species number and abundance of eutrophic species were dominant in Xinlicheng Reservoir. These species are organic pollution indicators Nitzschia 
acicularis from diatoms and mentioned earlier Microcystis aeruginosa as an active causative species of flowering in the period 2007-2011 (Sun, 2011; Kao et al., 2013). Thus, we can consider the summer season 2015 as very favorable for the reservoir, when bloom by Microcystis aeruginosa was not found, but its potential causative species is present in planktonic communities in noticeable quantities.

Table 2: Taxonomic list of algae and cyanobacteria in communities of the Xinlicheng Reservoir with codes, abundance scores and ecological preferences of revealed taxa, July 2015.

\begin{tabular}{|c|c|c|c|c|c|c|c|c|c|c|c|c|}
\hline Code & Taxa & Score & Hab & Reo & $\mathrm{pH}$ & $\mathrm{T}$ & Sal & $\mathrm{D}$ & Sap & S & $\begin{array}{l}\text { Aut- } \\
\text { Het }\end{array}$ & Tro \\
\hline \multicolumn{13}{|c|}{ Cyanobacteria } \\
\hline 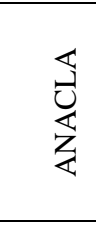 & $\begin{array}{l}\text { Anathece } \\
\text { clathrata (West } \\
\text { W. and West G. } \\
\text { S.) Komarek, } \\
\text { Kastovsky and } \\
\text { Jezberova }\end{array}$ & 5 & $\mathrm{P}$ & - & - & - & hl & - & b & 1.8 & - & me \\
\hline 忞 & $\begin{array}{l}\text { Aphanizomenon } \\
\text { flosaquae Ralfs } \\
\text { ex Bornet and } \\
\text { Flahault }\end{array}$ & 6 & $\mathrm{P}$ & - & - & - & hl & - & $\mathrm{b}$ & 2.1 & - & - \\
\hline 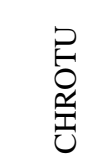 & $\begin{array}{l}\text { Chroococcus } \\
\text { turgidus } \\
\text { (Kützing) } \\
\text { Nägeli }\end{array}$ & 3 & P-B & aer & alf & - & hl & - & 0 & 1.3 & - & - \\
\hline $\begin{array}{l}\stackrel{2}{\omega} \\
\stackrel{7}{0} \\
0\end{array}$ & $\begin{array}{l}\text { Dolichospermum } \\
\text { spiroides } \\
\text { (Klebhan) } \\
\text { Wacklin, } \\
\text { Hoffmann L. } \\
\text { and Komárek }\end{array}$ & 1 & $\mathrm{P}$ & $\begin{array}{l}\text { st- } \\
\text { str }\end{array}$ & - & - & i & - & o-b & 1.5 & - & - \\
\hline 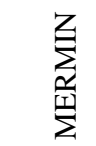 & $\begin{array}{l}\text { Merismopedia } \\
\text { minima } \\
\text { Beck G. }\end{array}$ & 2 & $\mathrm{~B}, \mathrm{~S}$ & aer & - & - & - & - & - & - & - & o \\
\hline 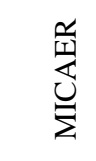 & $\begin{array}{l}\text { Microcystis } \\
\text { aeruginosa } \\
\text { (Kutzing) } \\
\text { Kutzing }\end{array}$ & 4 & $\mathrm{P}$ & - & - & - & hl & - & o-a & 2.1 & - & e \\
\hline 定 & $\begin{array}{l}\text { Microcystis } \\
\text { pulverea (Wood } \\
\text { H. C.) Forti }\end{array}$ & 4 & P-B & - & - & - & $\mathrm{i}$ & - & o-b & 1.5 & - & - \\
\hline
\end{tabular}


Table 2 (continued): Taxonomic list of algae and cyanobacteria in communities of the Xinlicheng Reservoir with codes, abundance scores and ecological preferences of revealed taxa, July 2015.

\begin{tabular}{|c|c|c|c|c|c|c|c|c|c|c|c|c|}
\hline \multicolumn{13}{|c|}{ Bacillariophyta } \\
\hline $\begin{array}{l}\text { I } \\
\text { 至 } \\
\text { 至 }\end{array}$ & $\begin{array}{l}\text { Diatoma } \\
\text { hyemalis (Roth) } \\
\text { Heiberg }\end{array}$ & 1 & P-B & $\begin{array}{l}\text { st- } \\
\text { str }\end{array}$ & ind & cool & hb & SX & b-o & 1.7 & ats & - \\
\hline 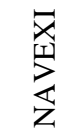 & $\begin{array}{l}\text { Navicula exigua } \\
\text { Gregory }\end{array}$ & 1 & B & str & alf & - & $\mathrm{i}$ & es & $x-0$ & 1.4 & ats & e \\
\hline 岕 & $\begin{array}{l}\text { Nitzschia } \\
\text { acicularis } \\
\text { (Kützing) Smith } \\
\text { W. }\end{array}$ & 4 & P-B & - & alf & $\begin{array}{c}\text { tem } \\
\mathrm{p}\end{array}$ & i & es & o-b & 2.7 & hce & e \\
\hline 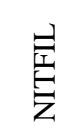 & $\begin{array}{l}\text { Nitzschia } \\
\text { filiformis (Smith } \\
\text { W.) Hustedt }\end{array}$ & 1 & B & $\begin{array}{l}\text { st- } \\
\text { str }\end{array}$ & alf & - & hl & es & $\mathrm{x}$ & 2.5 & hne & e \\
\hline 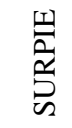 & $\begin{array}{l}\text { Surirella } \\
\text { peisonis } \\
\text { Pantocsek }\end{array}$ & 1 & B & - & - & - & - & - & $\mathrm{a}$ & - & - & - \\
\hline 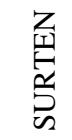 & $\begin{array}{l}\text { Surirella tenera } \\
\text { Gregory W. }\end{array}$ & 1 & P-B & st & alf & - & $\mathrm{i}$ & es & o & 1.0 & - & e \\
\hline \multicolumn{13}{|c|}{ Chlorophyta } \\
\hline 忌 & $\begin{array}{l}\text { Acutodesmus } \\
\text { acuminatus } \\
\text { (Lagerheim) } \\
\text { Tsarenko P. M. }\end{array}$ & 4 & P-B & $\begin{array}{l}\text { st- } \\
\text { str }\end{array}$ & ind & - & $\mathrm{i}$ & - & b & 2.1 & - & - \\
\hline 㞼 & Carteria sp. & 1 & - & - & - & - & - & - & - & 2.3 & - & - \\
\hline 东 & $\begin{array}{l}\text { Cladophora } \\
\text { glomerata } \\
\text { (Linnaeus) } \\
\text { Kützing }\end{array}$ & 6 & P-B & $\begin{array}{l}\text { st- } \\
\text { str }\end{array}$ & alf & - & i & - & b-o & 1.9 & - & - \\
\hline
\end{tabular}


Table 2 (continued): Taxonomic list of algae and cyanobacteria in communities of the Xinlicheng Reservoir with codes, abundance scores and ecological preferences of revealed taxa, July 2015.

\begin{tabular}{|c|c|c|c|c|c|c|c|c|c|c|c|c|}
\hline 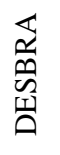 & $\begin{array}{l}\text { Desmodesmus } \\
\text { brasiliensis } \\
\text { (Bohlin) } \\
\text { E.Hegewald }\end{array}$ & 1 & P-B & $\begin{array}{l}\text { St- } \\
\text { str }\end{array}$ & - & - & - & - & b & 2.0 & - & - \\
\hline 空 & $\begin{array}{l}\text { Eudorina } \\
\text { elegans } \\
\text { Ehrenberg }\end{array}$ & 3 & $\mathrm{P}$ & $\begin{array}{l}\text { St- } \\
\text { str }\end{array}$ & - & - & $\mathrm{i}$ & - & b & 2.3 & - & - \\
\hline 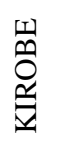 & $\begin{array}{l}\text { Kirchneriella } \\
\text { obesa (West) } \\
\text { West and West } \\
\text { G. S. }\end{array}$ & 2 & P-B & $\begin{array}{l}\text { St- } \\
\text { str }\end{array}$ & - & - & $\mathrm{i}$ & - & b & 1.8 & - & - \\
\hline 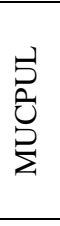 & $\begin{array}{l}\text { Mucidosphaeriu } \\
\text { m pulchellum } \\
\text { (Wood H. C.) } \\
\text { Bock C., } \\
\text { Proschold and } \\
\text { Krienitz } \\
\end{array}$ & 2 & P-B & $\begin{array}{l}\text { st- } \\
\text { str }\end{array}$ & ind & - & $\mathrm{i}$ & - & b & 2.3 & - & - \\
\hline 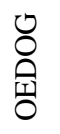 & Oedogonium sp. & 3 & B & - & - & - & - & - & - & - & - & - \\
\hline 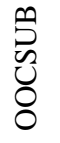 & $\begin{array}{l}\text { Oocystis } \\
\text { submarina } \\
\text { Lagerheim }\end{array}$ & 3 & P-B & st & - & - & $\mathrm{i}$ & - & - & - & - & - \\
\hline 号 & $\begin{array}{l}\text { Pediastrum } \\
\text { duplex Meyen }\end{array}$ & 4 & $\mathrm{P}$ & $\begin{array}{l}\text { st- } \\
\text { str }\end{array}$ & ind & - & $\mathrm{i}$ & - & o-a & 2.1 & - & - \\
\hline 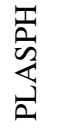 & $\begin{array}{l}\text { Planctococcus } \\
\text { sphaerocystiformis } \\
\text { Korshikov }\end{array}$ & 3 & $\mathrm{P}$ & st & - & - & - & - & - & - & - & - \\
\hline $\begin{array}{l}\bar{a} \\
\omega \\
0 \\
0\end{array}$ & $\begin{array}{l}\text { Polyedriopsis } \\
\text { spinulosa } \\
\text { (Schmidle) } \\
\text { Schmidle }\end{array}$ & 2 & P & st & - & - & - & - & b & 1.9 & - & - \\
\hline
\end{tabular}


Table 2 (continued): Taxonomic list of algae and cyanobacteria in communities of the Xinlicheng Reservoir with codes, abundance scores and ecological preferences of revealed taxa, July 2015.

\begin{tabular}{|c|c|c|c|c|c|c|c|c|c|c|c|c|}
\hline 究 & $\begin{array}{l}\text { Scenedesmus } \\
\text { arcuatus } \\
\text { (Lemmermann) } \\
\text { Lemmermann }\end{array}$ & 1 & P-B & $\begin{array}{l}\text { st- } \\
\text { str }\end{array}$ & - & - & $\mathrm{i}$ & - & $0-a$ & 1.9 & - & - \\
\hline 崡 & $\begin{array}{l}\text { Scenedesmus } \\
\text { ellipticus } \\
\text { Corda }\end{array}$ & 3 & P-B & $\begin{array}{l}\text { st- } \\
\text { str }\end{array}$ & - & - & - & - & o-b & - & - & - \\
\hline 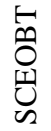 & $\begin{array}{l}\text { Scenedesmus } \\
\text { obtusus } \\
\text { Meyen }\end{array}$ & 1 & P-B & $\begin{array}{l}\text { St- } \\
\text { str }\end{array}$ & - & - & - & - & b & 1.8 & - & - \\
\hline 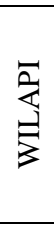 & $\begin{array}{l}\text { Willea apiculata } \\
\text { (Lemmermann) } \\
\text { John D. M., } \\
\text { Wynne M. J. } \\
\text { and Tsarenko P. } \\
\text { M. }\end{array}$ & 1 & $\mathrm{P}$ & - & - & - & - & - & b & 2.2 & - & - \\
\hline \multicolumn{13}{|c|}{ Charophyta } \\
\hline 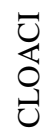 & $\begin{array}{l}\text { Closterium } \\
\text { aciculare } \\
\text { West T. }\end{array}$ & 1 & $\mathrm{P}$ & $\begin{array}{l}\text { st- } \\
\text { str }\end{array}$ & alf & - & - & - & b-o & 1.7 & - & - \\
\hline 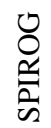 & Spirogyra sp. & 2 & B & - & - & - & - & - & - & - & - & - \\
\hline
\end{tabular}

Note: Abbreviation for ecological groups: Habitat preferences (Hab): B, benthic; P-B, planktonicbenthic; P, planktonic. Streaming and Oxygenation (Reo): aer, aerophiles, str, streaming waters inhabitant; st-str, low streaming waters inhabitant; st, standing water inhabitant. Water $\mathrm{pH}(\mathrm{pH})$ : ind, indifferent; alf, alkaliphil. Water temperature (T): cool, cool-loving species; temp, temperate temperature water inhabitants. Water salinity (Sal): hb, halophobe; i, oligohalobious-indifferent; hl, oligohalobious-halophilous. Organic pollution, Watanabe (D): es, eurysaprobes; sp, saprophiles. Organic pollution and self-purification zones by Sládeček (Sap): indicators of Class of Water Quality I: x-o - 0.4 - xeno-oligosaprobiont; Class of Water Quality II: o - 1.0 - oligosaprobiont; o-b - 1.4 - oligobeta-mesosaprobiont; Class of Water Quality III: x-a -1.55 - xeno-alpha-mesosaprobiont; b-o - 1.6 beta-oligosaprobiont; o-a - 1.8 - oligo-alpha-mesosaprobiont; b - 2.0 - beta-mesosaprobiont. Index saprobity s (S): species-specific index saprobity according Sládeček. Nutrition type as Nitrogen uptake metabolism (Aut-Het): ats, nitrogen-autotrophic taxa, tolerating very small concentrations of organically bound nitrogen; hne, facultatively nitrogen-heterotrophic taxa, needing periodically elevated concentrations of organically bound nitrogen; hce, nitrogen-heterotrophic taxa, needing elevated concentrations of organically bound nitrogen. Trophic state (Tro): o, oligotrafentic; me, mesoeutraphentic; e, eutraphentic. The most abundance scores 4 and above are bolded. 


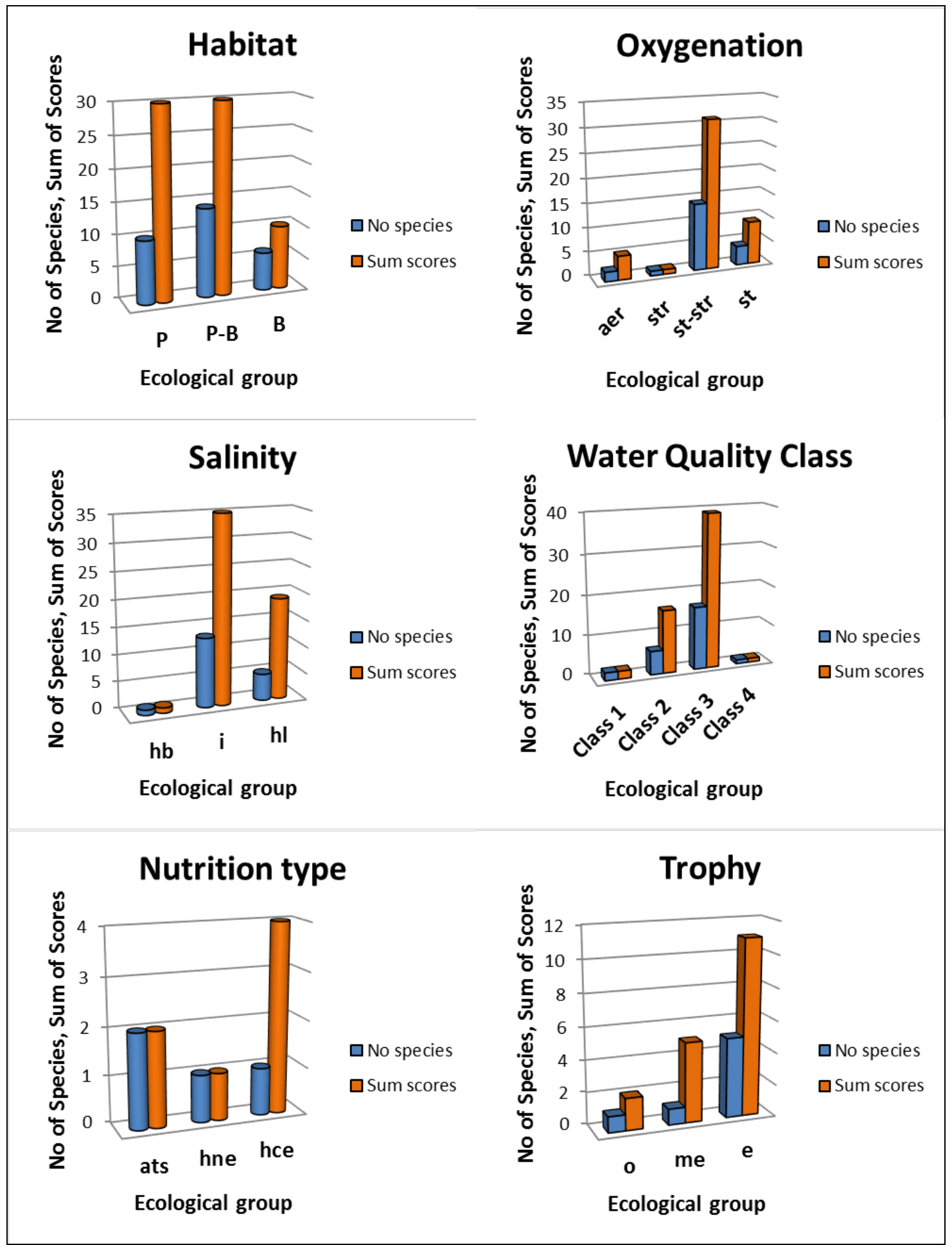

Figure 5: Distribution of algal species frequency scores and species number in Division in the Xinlicheng Reservoir, July 2015.

Ecological group abbreviation as in table 2. 


\section{Comparative statistics}

A comparative approach provided for the grouping of algal communities with respect to their indicator value similarity. A similar plot of indicator compositions that was constructed for the Xinlicheng Reservoir communities showed two clusters at the similarity level of $50 \%$ (Fig. 6). Cluster 1 includes indicators of the most variables from which the closely related were groups of diatom indicators of organic pollution (D), indicators of nutrition type (Aut-Het), $\mathrm{pH}$, and trophic state (Tro). The second cluster is negatively related to the first and unified abundance of species (Score) and its habitat preferences (Hab). Despite the fact that few data were collected for analysis, based on the correlation analysis of bioindicator groups, it can be said that the abundance of species and their association with the substrate is a common characteristic of the reservoir. In contrast, the most important groups for monitoring are indicators of trophicity and organic pollution.

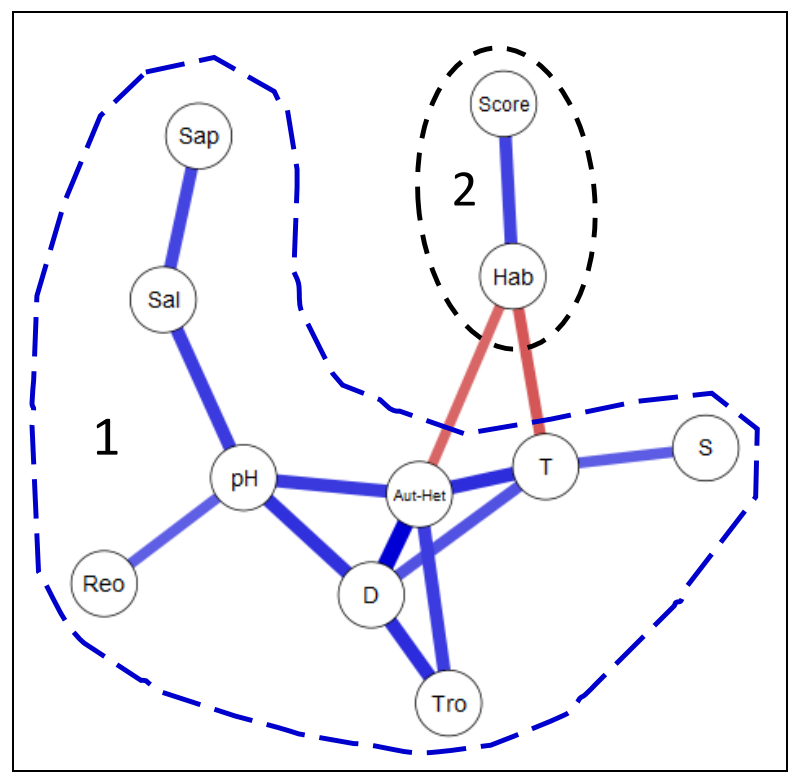

Figure 6: Indicator species correlation plot constructed in JASP of R-statistica program for the Xinlicheng Reservoir, July 2015. The indicated cariables placed in the net corners. The line thickness reflect of the correlation volume. The line color reflect positive (blue) or negative

(red) correlations. The thickness of connected lines is corresponding to the percent of similarity that stay on the lines. Large circles marked by black or blue dushed lines are represent the indicator cores.

\section{Canonical Correspondence Analysis}

To continue the statistical analysis of species and environment relationships, we constructed Canonical Correspondence Analysis (CCA) plots based on environmental and biological variables of the studied reservoir water (Tabs. 1 and 2). A triplot of the most abundant species number in the communities of the Xinlicheng Reservoir and environmental variables demonstrated grouping of parameters in one arrow because the measurements were done on one date and studied sites are close positioning (Fig. 7a). Nevertheless, it can be seen in the dshed outline that Diatoma hyemalis, Navicula exigua, Nitzschia filiformis, and Surirella peisonis from diatoms and Scenedesmus arcuatus from green algae can be indicators, which positively related to revealed summer variables of the Xinlicheng Reservoir. 
CCA of the most abundant species from table 2 with abundance scores four-six indicated that there were six species which included mostly cyanobacteria (Anathece clathrata, Aphanizomenon flosaquae, Microcystis aeruginosa, and M. pulverea), and only one species of diatoms and two of greens (Nitzschia acicularis, and Pediastrum duplex, Acutodesmus acuminatus, respectively) (Fig. 7b). All abundant species increase their numbers with an increase in the identified environmental variables, except for Acutodesmus acuminatus, which, on the contrary, developed more comfortably with lower values of variables.
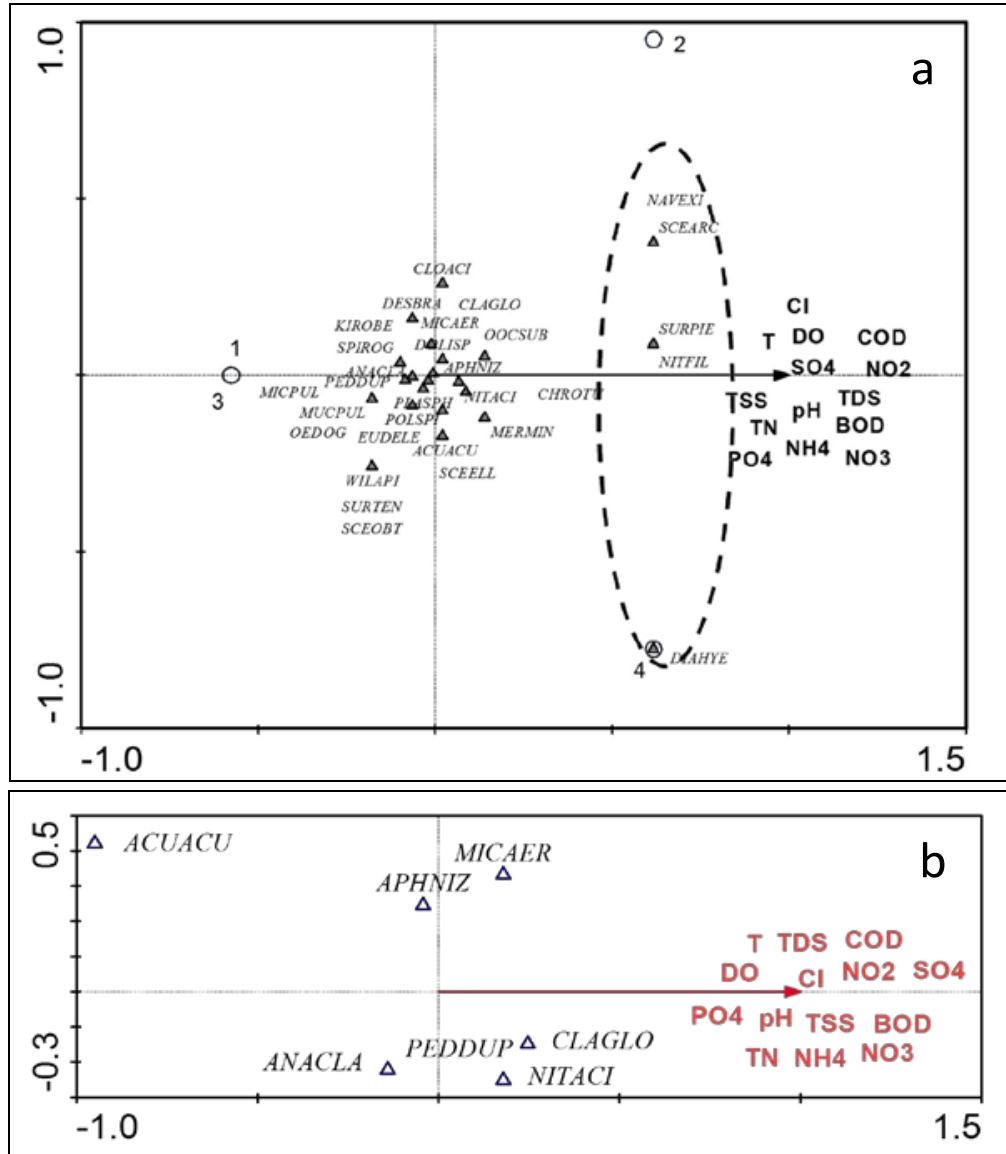

Figure 7a-b: CCA plots of algae and cyanobacteria species (a), and scores of abundant species (b), and environmental variables relationships in the Xinlicheng Reservoir, July 2015.

Monte Carlo test result: significance of all canonical axes $=0.013, P$-value $=0.0880$.

\section{Indices}

We calculated Index saprobity $\mathrm{S}$ for assessing organic pollution value in the Xinlicheng Reservoir in summer of 2015. Table 1 shows that $S$ value fluctuated in a small range between 1.85 and 1.97, which correspond to Class 3 of water quality, 3a self-purification zone and rank 4. Nitric nitrogen concentration (Tab. 1) can be corresponded to Class 3 of water quality, 3b self-purification zone and rank 5 (Barinova 2017b). Therefore, it can give us a base for calculation of the index of toxic impact to the algal community, the WESI, which was $4 / 5=$ 0.8 . As was mentioned in the Methods section, this value of index corresponds to low toxic influence to photosynthesis of inhabitant algae and cyanobacteria in the Xinlicheng Reservoir. 
The Shannon index can be used for the water quality evaluation according to Wilhm and Dorris (1968) and Staub et al. (1970). This index values for algal communities in the Xinlicheng Basin varied from 3.259 to 3.312, corresponding to clean or slightly polluted water.

\section{CONCLUSIONS}

A total of 31 species of algae and cyanobacteria were identified in the 20 samples collected in July of 2015 in the Xinlicheng Reservoir in the frame of the Sino-Israeli International Scientific Expedition. Measured water properties confirm the fresh water with low to middle organic pollution by allochthonous nutrients. Bioindicator analysis was implemented for the first time for this important source of drinking water used by Changchun City. Because problems have arisen with the decreasing water quality that has been impacted a few times from 2007-2011 by an algal bloom, we revealed potential threatening cyanobacteria species. We assessed the significant variables, the increasing of which can provoke the bloom. Bioindication demonstrated that water was low saline, low alkaline, middle oxygenated fresh waters 3 Class of water quality with low dissolved ions. However, we found species indicators that have the heterotrophic properties with high frequency that reflect the toxic impact to photosynthesis of the primary producers in the reservoir. The calculated WESI index allows us to confirm the pollution impact on the ecosystem level due to the input of nutrients from the reservoir catchment area. As a whole, the water in the studied reservoir was assessed by bioindicators as eutrophic. This may be the highest trophic level during the year, because we took samples during the period of the most active functioning of the aquatic ecosystem. We cannot compare our list of species with previous studies in this reservoir because only two species were previously mentioned and that study was based on the chemistry and concentration of chlorophyll. In any case, we find improving water quality from 2007 up to 2015. The species list that could be a cause of the water bloom in the future was revealed with the help of statistics and represented variables, which can be recommended for monitoring.

\section{ACKNOWLEDGEMENTS}

This work has been backed by Applied Basic Research Projects of Jilin Science and Technology Department (20130102049JC) China, and Israeli Ministry of Aliyah and Integration.

\section{REFERENCES}

1. Barinova S. S., 1997 - Morphology of connective spines in diatom algae of the genus Aulacoseira Thwaites, Paleontological Journal, Moscow, 31, 239-245.

2. Barinova S., 2017a - How to align and unify the cell counting of organisms for bioindication, International Journal of Environmental Sciences and Natural Resources, 2, 1-3, doi: 10.19080/IJESNR.2017.02.555585.

3. Barinova S., 2017b - On the classification of water quality from an ecological point of view, International Journal of Environmental Sciences and Natural Resources, 2, 1-8, doi: 10.19080/IJESNR.2017.02.555581.

4. Barinova S. S., Medvedeva L. A. and Anissimova O. V., 2006 - Diversity of algal indicators in environmental assessment, Tel Aviv, Pilies Studio, 458. (in Russian)

5. Barinova S. S., Medvedeva L. and Nevo E., 2008 - Regional influences on algal biodiversity in two polluted rivers of Eurasia by bio-indication and Canonical Correspondence Analysis (CCA), Applied Ecology and Environmental Research, 6, 4, 29-55.

6. Barinova S. S., Bragina T. M. and Nevo E., 2009 - Algal species diversity of arid region lakes in Kazakhstan and Israel, Community Ecology, 10, 7-16, doi: 10.1556/ComEc.10.2009.1.2.

7. Barinova S., Keshri J. P., Ghosh S. and Sikdar J., 2012 - The influence of the monsoon climate on phytoplankton in the Shibpukur pool of Shiva temple in Burdwan, West Bengal, India, Limnological Review, 2, 47-63, doi: 10.2478/v10194-011-0044.

8. Barinova S. S., Medvedeva L. A., Kondratieva L. M. and Shesterkin V. P., 2015 - Bio-indication in Amur River, Research Journal of Pharmaceutical, Biological and Chemical Sciences, 6, 1, 1171-1187. 
9. Barinova S., Liu N., Ding J., An Y. and Qin X et al., 2016 - Ecological assessment of water quality of the Songhua River upper reaches by algal communities, Acta Ecologica Sinica, 36, 126-132, doi: 10.1016/j.chnaes.2015.12.001.

10. Barinova S., Bilous O. and Tsarenko P. M., 2019 - Algal indication of water bodies in Ukraine: methods and perspectives, Haifa University Publishing House, Haifa, Kiev, 367.

11. BBC News, 2007 - China to clean up polluted lake, 27 October.

12. Bellinger E. G. and Sigee D. C., 2010 - Freshwater algae: identification and use as bioindicators, Chichester, John Wiley and Sons, 271.

13. Berdnikov N. V., Rapoport V. L., Rybas O. V., Pelykh T. I., Zolotukhina G. F. and Zazulina V. Ye., 2006 - Monitoring of the Amur River ecosystem pollution resulting from the accident at the chemical plant in Jilin (China): nitrobenzene, Tihookeanskaya geologiya, 25, 5, 94-63.

14. Browder G. J., Shiqing Xie, Yoonhee Kim, Lixin Gu, Mingyuan Fan, Ehrhardt D., 2007 - Improving the performance of China's urban water utilities, New York, Washington DC, The International Bank for Reconstruction and Development / The World Bank, 176.

15. Guiry M. D. and Guiry G. M., 2018 - AlgaeBase, World-Wide electronic publication, Galway, Ireland: National University of Ireland, Galway (online), http://www.algaebase.org/, June 2020.

16. Heywood V., 2004 - Modern approaches to floristics and their impact on the region of SW Asia, Turkish Journal of Botany, 28, 1-2, 7-16.

17. Kao J., Wen-Pei S. and Ran C., 2013 - Analysis of phytoplankton and eutrophication in Xinlicheng Reservoir, Advanced Materials Research, 779-780, 1230-1233.

18. John D. M., Whitton B. A. and Brook A. J. (eds), 2011 - The freshwater algal flora of the British Isles: an identification guide to freshwater and terrestrial algae, Cambridge University Press, 878.

19. Krammer K. and Lange-Bertalot H., 1986 - Bacillariophyceae, Teil 1, Naviculaceae, in Süßwasserflora von Mitteleuropa, Band 2, Ettl H., Gerloff J., Heynig H. and Mollenhauer D. (eds), Berlin, Germany, Gustav Fischer Verlag, 876. (in German)

20. Krammer K. and Lange-Bertalot H., 1988 - Bacillariophyceae, Teil 2. Epithemiaceae, Bacillariaceae, Surirellaceae, in Süßwasserflora von Mitteleuropa, Band 2, Ettl H., Gerloff J., Heynig H. and Mollenhauer D. (eds), Berlin, Germany, Gustav Fischer Verlag. 596. (in German).

21. Krammer K. and Lange-Bertalot H., 1991a - Bacillariophyceae, Teil 3, Centrales, Fragilariaceae, Eunotiaceae, in Süßwasserflora von Mitteleuropa, Band 2, Ettl H., Gerloff J., Heynig H. and Mollenhauer D. (eds), Berlin, Germany, Gustav Fischer Verlag. 576. (in German)

22. Krammer K. and Lange-Bertalot H., 1991b - Bacillariophyceae, Teil 4, Achnanthaceae, Kritische Ergänzungen zu Navicula (Lineolatae) und Gomphonema, in Süßwasserflora von Mitteleuropa, Band 2, Ettl H., Gerloff J., Heynig H. and Mollenhauer D. (eds), Gustav Fischer Verlag. 437. (in German)

23. Li Y. and Han D., 2007 - Water environment protection problems, Journal of Jilin Water Resources, 12, 1-2.

24. Love J., Selker R., Marsman M., Jamil T., Dropmann D., Verhagen A. J., Ly A., Gronau Q. F., Smira M., Epskamp S., Matzke D., Wild A., Rouder J. N., Morey R. D. and Wagenmakers E. J., 2019 - JASP: graphical statistical software for common statistical designs, Journal of Statistical Software, 88, 2, 1-17.

25. Ma X., 2002 - China's environmental governance, 2007-02-21.

26. Staub R., Appling J. W., Hofstetter A. M. and Haas I. J., 1970 - The effects of industrial wastes of Memphis and Shelby County on primary planktonic producers, BioScience, 20, 16, 905-912.

27. Sun L. L., 2011 - Study on water quality characteristics and eutrophication trends based on al method in Xinlicheng Reservoir, Changchun, Environmental Engineering, 23.06.2011.

28. Swift E., 1967 - Cleaning diatom frustules with ultraviolet radiation and peroxide, Phycologia, 6, 161-163.

29. Ter Braak C. J. F. and Šmilauer P., 2002 - CANOCO reference manual and CanoDraw for Windows user's guide: software for Canonical Community Ordination (4.5), Ithaca, Microcomputer Power Press.

30. Wilhm J. L. and Dorris T. C., 1968 - Biological parameters for water quality, BioScience, 18, 447-481.

31. Xian F. Z., Chang L. X., Yong Q. L. and Ding F. S., 2014 - Water Environmental Quality Assessment and Protection Strategies of the Xinlicheng Reservoir, China, Applied Mechanics and Materials, 501-504, 1863-1867.

32. Xian F. Z., Chang L. X. and Yong Q. L., 2013 - Seasonal variations of the water quality in the Xinlicheng Reservoir, China, Advanced Materials Research, 864-867, 2408-2412.

33. Zalewski M., 2000 - Ecohydrology - the scientific background to use ecosystem properties as management tools towards sustainability of water resources, Ecological Engineering, 165, 1-8. 